\title{
JURNAL KIMIA DAN KEMASAN
}

(JOURNAL OF CHEMICAL AND PACKAGING)

\section{Terakreditasi Kemenristek Dikti : No. 51/E/KPT/2017}

Jurnal Kimia dan Kemasan memuat hasil penelitian dan telaah ilmiah bidang kimia dan kemasan yang belum pernah dipublikasikan. Jurnal Kimia dan Kemasan terbit dua nomor dalam setahun (April dan Oktober)

Penanggungjawab Officially incharge

Ketua Dewan Redaksi Chief Editor

Dewan Redaksi Editorial board

Mitra Bestari Peer Reviewer

Redaksi Pelaksana

\section{Kepala Balai Besar Kimia dan Kemasan \\ Head of Center for Chemical and Packaging}

DR. Dwinna Rahmi (Kimia/Chemistry)

Balai Besar Kimia dan Kemasan, Jl. Balai Kimia No.1. Pekayon Kalisari, Pasar Rebo. Jakarta Timur 13069. Kotak Pos. 6916 JATPK.

DR. Rahyani Ermawati (Biokimia/Biochemistry)

Balai Besar Kimia dan Kemasan

DR. Siti Agustina (Kimia/Chemistry)

Balai Besar Kimia dan Kemasan

Dra. Yemirta, M.Si (Kimia/Chemistry)

Balai Besar Kimia dan Kemasan

Ir. Emmy Ratnawati (Kimia/Chemistry)

Balai Besar Kimia dan Kemasan

Retno Yunilawati, SSi, MSi (Kimia/Chemistry)

Balai Besar Kimia dan Kemasan

Evana Yuanita, ST, MT (Polimer/Polymer)

Balai Besar Kimia dan Kemasan

\section{Prof. DR. Slamet, MT (Kimia/Chemistry)}

Departemen Teknik Kimia, Fakultas Teknik, Universitas Indonesia, Kampus UI Depok Email : slamet@che.ui.ac.id (h-index : 4 scopus)

DR. Etik Mardliyati (Biokimia/Biochemistry)

BPPT Gd II Lt 16, JI MH Thamrin 8 Jakarta

Email : etik.mardliyati@bppt.go.id

DR. Mochamad Chalid, S.Si, M. Sc,Eng (Polimer/Polymer)

Departemen Teknik Metalurgi dan Material, Fakultas Teknik Universitas Indonesia

Kampus UI Depok

Email : mchalid@yahoo.com (h-index : 5 scopus)

Nofrijon Sofyan, Ph.D

Departemen Metalurgi dan Material, Fakultas Teknik Universitas Indonesia

Kampus UI Depok

Email : nofrijon.sofyan@ui.ac.id (h-index : 5 scopus)

Dr. Andria Agusta

Pusat Penelitian Biologi LIPI, Cibinong, Bogor

Email : andria.agusta@lipi.go.id (h-index : 4 scopus)

Dr. Endang Warsiki (Polimer/Polymer)

Fakultas Teknologi Pertanian ( FATETA), Institut Pertanian Bogor

Email : endang.warsiki@gmail.com (h-index : 5)

Dr. Sudirman

Pusat Sains dan Teknologi Bahan Maju (PSTBM) - BATAN, Serpong Indonesia

Email : sudirmanoemar@gmail.com (h-index: 2 scopus)

Dedi Noviendri, Ph.D

Balai Besar Riset Pengolahan Produk dan Bioteknologi Kelautan dan Perikanan (KKP), Indonesia

Email : dedinov@yahoo.com (h-index = 7 scopus)

Prof. Dr. Irmanida Batubara

Divisi Kimia Analitik, Departemen Kimia IPB

Email : ime@ipb.ac.id (h-index = 10 scopus)

Fadlilatul Taufany, ST., Ph.D.

Departemen Teknik Kimia, Fak. teknologi Industri, ITS, Indonesia

Email : f_taufany@chem.eng.its.ac.id (h-index = 7 scopus)
Agustina Arianita Cahyaningtyas, ST
Chicha Nuraeni, ST
Novi Nur Aidha, ST
Ira Setiawati, S.T.

Rizka Karima, S.Si.

Rustanto, ST

Tiara Mailisa, S.TP

\footnotetext{
Alamat (Address)

Balai Besar Kimia dan Kemasan

Badan Penelitian dan Pengembangan Industri, Kementerian Perindustrian

Jl. Balai Kimia No. 1, Pekayon, Pasar Rebo, Jakarta Timur, Telepon : (021) 8717438, Fax : (021) 8714928

E-mail : jurnal_kimiakemasan@yahoo.com
} 


\title{
JURNAL KIMIA DAN KEMASAN
}

\author{
(JOURNAL OF CHEMICAL AND PACKAGING)
}

Terakreditasi Kemenristek Dikti : No. 51/E/KPT/2017

\section{Daftar Isí}

Green Synthesis Nanopartikel ZnO Menggunakan Media Ekstrak Daun Tin (Ficus Carica Linn)

Iwan Syahjoko Saputra, Siti Suhartati, Yoki Yulizar, dan Sudirman

Ekstrak Bunga Tapak Kuda (Ipomoea pescaprae L. Sweet) sebagai Medium Sintesis Nanopartikel Emas

Aswin Falahudin, Salprima Yudha S., Irfan Gustian, Morina Adfa, Charles Banon, dan Teja Dwi Sutanto

Aktivitas Antimikroba Partikel Nano CaO dari Kulit Kerang Mutiara (Pinctada maxima) $14-19$ Kendri Wahyuningsih dan Lovy Perdani

Peningkatan Siifat Fisika Kimia Membran Selulosa Asetat Menggunakan Polifungsional Monomer Trimethallyl Isocyanurate

Meri Suhartini, Santoso P., E. Ernawati, dan A.Y. Panjaitan

Pengembangan Bioplastik Antibakteri Morgonella morganii sebagai Kemasan Makanan

Eviomitta Rizki Amanda, Khoirun Nisyak, dan Yulianto Ade Prasetya 


\title{
JURNAL KIMIA DAN KEMASAN
}

(JOURNAL OF CHEMICAL AND PACKAGING)

\author{
Terakreditasi Kemenristek Dikti : No. 51/E/KPT/2017
}

\section{Kata Pengantar}

Jurnal Kimia dan Kemasan Volume 42 Nomor 1 April 2020 ini merupakan terbitan ketujuh secara online atau Online Journal System (OJS). Pada terbitan ini, selain terakreditasi LIPI, jurnal ini juga terakreditasi Kemenristek Dikti. Ruang lingkup jurnal dipersempit menjadi kimia terapan yaitu mencakup bahan alam, biopolimer, sintesa kimia dan permasalahan dalam proses kimia dan peralatan serta bahan dan teknologi kemasan Materi untuk terbitan volume 42 Nomor 1 April 2020 ini memuat lima artikel penelitian bidang kimia dan kemasan. Artikel pertama sampai ketiga membahas tentang artikel bidang kimia yaitu tentang sintesis nanopartikel. Artikel pertama dan kedua membahas tentang sintesis nanopartikel dengan pendekatan green sinthyesis yaitu artikel pertama yang berjudul Green Synthesis Nanopartikel Zno Menggunakan Media Ekstrak Daun Tin (Ficus carica Linn) dan artikel kedua berjudul Ekstrak Bunga Tapak Kuda (Ipomoea Pescaprae L. Sweet) sebagai Medium Sintesis Nanopartikel Emas. Artikel ketiga masih membahas tentang nanopartikel dan aktifitas antimikrobanya yang berjudul Aktivitas Antimikroba Partikel Nano CaO Dari Kulit Kerang Mutiara (Pinctada Maxima). Artikel keempat membahas tentang membran selulosa asetat untuk pemurnian minyak atsiri, dengan judul Peningkatan Sifat Fisika Kimia Membran Selulosa Asetat Menggunakan Polifungsional Monomer Trimethallyl Isocyanurate. Artikel kelima merupakan penelitian bidang kemasan yang membahas tentang bioplastik dengan judul Pengembangan Bioplastik Antibakteri Morganella Morganii Sebagai Kemasan Makanan.

Kelima topik bahasan dalam terbitan ini semoga bermanfaat bagi perkembangan ilmu pengetahuan dan dapat menambah wawasan para pembaca sekalian. Akhir kata redaksi sangat bersyukur atas naskah yang masuk dari berbagai Institusi, Lembaga Penelitian ataupun dari Perguruan Tinggi. Seiring dengan berkembangnya jaringan, redaksi berharap akan semakin banyak naskah karya tulis ilmiah yang masuk sesuai ruang lingkup untuk dapat diterbitkan dalam Jurnal ini. Kritik dan saran untuk peningkatan kualitas penerbitan jurnal ini sangat kami harapkan. 


\section{PEDOMAN PENULISAN KTI JURNAL KIMIA DAN KEMASAN}

\section{Sistematika Penulisan}

1.1. Naskah dalam bentuk Makalah Lengkap (full paper) atau Original Research meliputi unsurunsur sebagai berikut:

1.1.1. Judul

1.1.2. Nama, alamat penulis, dan email

1.1.3. Abstrak (memuat latar belakang secara ringkas, tujuan, metode, hasil serta kesimpulan)

1.1.4. Kata kunci

1.1.5. Pendahuluan (antara lain latar belakang, perumusan masalah, tujuan, teori, ruang lingkup penelitian, dan hipotesis [opsional]).

1.1.6. Bahan dan metode (waktu dan tempat, bahan dan alat, metode/cara pengumpulan data, metode analisis data)

1.1.7. Hasil dan pembahasan (memuat data atau fakta yang diperoleh dari penelitian dan ulasan tentang hasil, termasuk tabel dan gambar)

1.1.8. Kesimpulan

1.1.9. Saran (optional)

1.1.10. Ucapan terima kasih (optional)

1.1.11. Daftar pustaka (minimal 10 daftar pustaka, $80 \%$ acuan primer/jurnal, referensi kemutakhiran 5-10 tahun terakhir)

1.2. Naskah dalam bentuk Ulasan (review) meliputi unsur-unsur sebagai berikut:

1.2.1. Judul

1.2.2. Nama, alamat penulis, dan email

1.2.3. Abstrak

1.2.4. Kata kunci

1.2.5. Pendahuluan

1.2.6. Pembahasan

1.2.7. Kesimpulan

1.2.8. Ucapan terima kasih (optional)

1.2.9. Daftar pustaka (minimal 25 daftar pustaka, $80 \%$ acuan primer/jurnal, referensi kemutakhiran 5 tahun terakhir)

\section{Standar Umum Penulisan}

2.1. Naskah ditulis dalam bahasa Indonesia atau bahasa Inggris

2.2. Judul, abstrak, da kata kunci harus ditulis dalam dua bahasa (Indonesia dan Inggris).

2.3. Ditulis menggunakan MS Word pada kertas ukuran A4, font Arial ukuran 10, spasi 1, batas atas $2 \mathrm{~cm}$, batas bawah $2 \mathrm{~cm}$, batas kiri $3 \mathrm{~cm}$, batas kanan $2.1 \mathrm{~cm}$, multiple pages mirror margin, section start continous, header \& footer different odd \& even, header $1.5 \mathrm{~cm}$, dan footer $1.5 \mathrm{~cm}$.

2.4. Judul, abstrak, dan kata kunci ditulis dalam format satu kolom. Sedangkan bagian-bagian naskah selanjutnya ditulis dalam dua kolom dengan format justified, first line indent $1 \mathrm{~cm}$, arial 10, spasi 1 , dan jarak antar kolom $0.6 \mathrm{~cm}$.

2.5. Penyebutan istilah diluar bahasa Indonesia atau Inggris ditulis dengan huruf cetak miring (italic).

2.6. Jumlah halaman maksimal 10 halaman.

\section{Cara Penulisan Judul}

3.1. Judul mencerminkan inti tulisan, diketik dengan huruf capital cetak tebal (bold), diletakkan ditengah-tengah (centered) dengan menggunakan font Arial 14, spasi 1. 
3.2. Apabila judul ditulis dalam bahasa Indonesia, maka dibawahnya ditulis ulang dalam bahasa Inggris, dan sebaliknya. Diketik dengan huruf capital cetak tebal (bold), diletakkan ditengahtengah (centered) dengan menggunakan font Arial 11, spasi 1.

3.3. Apabila KTI menggunakan bahasa Indonesia, maka judul dalam bahasa Inggris ditulis dengan huruf cetak miring (italic), sedangkan judul dalam bahasa Indonesia ditulis tidak dengan huruf cetak miring, dan sebaliknya.

\section{Cara Penulisan Nama, Alamat, dan Email}

4.1. Nama penulis diketik di bawah judul, ditulis lengkap tanpa menyebutkan gelar, diletakkan di tengah-tengah (centered), diketik dengan huruf regular, menggunakan font Arial 12, spasi 1.

4.2. Alamat penulis (nama dan alamat instansi tempat bekerja) ditulis lengkap di bawah nama penulis, diletakkan di tengah-tengah (centered), diketik dengan huruf regular, menggunakan font Arial 10, spasi 1.

4.3. Alamat Pos-el (e-mail) ditulis di bawah alamat penulis, diletakkan di tengah-tengah (centered), diketik dengan huruf regular, menggunakan font Arial 10, spasi 1.

4.4. Jika penulis terdiri lebih dari satu orang, maka harus ditambahkan kata penghubung "dan" (bukan lambang " $\&$ ").

4.5. Jika penulis lebih dari satu orang dan berbeda instansi maka dituliskan angka superscript di belakang nama berdasar angka urutan instansi

4.6. Jika alamat penulis lebih dari satu, maka harus diberi tanda angka superscript dan diikuti alamat sekarang.

\section{Cara Penulisan Abstrak dan Kata Kunci}

5.1. Abstrak ditulis dalam satu paragraf, ditulis dalam dua bahasa (Indonesia dan Inggris), menggunakan font Arial 9, spasi 1, format justified.

5.2. Abstrak dalam bahasa Indonesia paling banyak 250 kata, sedangkan abstract dalam bahasa Inggris paling banyak 200 kata.

5.3. Penempatan abstrak disesuaikan dengan bahasa yang digunakan dalam KTI. Apabila KTI menggunakan bahasa Indonesia, maka abstrak didahulukan dalam bahasa Indonesia ditulis dengan huruf cetak regular (tidak dengan huruf cetak miring), sedangkan abstract dalam bahasa Inggris ditulis dengan huruf cetak miring (italic), dan sebaliknya.

5.4. Kata abstrak (abstract) ditulis dengan huruf kapital cetak tebal (bold), menggunakan font Arial 10.

5.5. Abstrak dalam bahasa Indonesia diikuti kata kunci dalam bahasa Indonesia, sedangkan abstract dalam bahasa Inggris diikuti keywords dalam bahasa Inggris.

5.6. Kata kunci ditulis menggunakan font Arial 9.

5.7. Kata kunci terdiri dari minimal tiga kata.

\section{Cara Penulisan Bab (heading)}

6.1. Bab, ditulis dengan format huruf kapital, rata kiri, bold, font Arial 10, spasi 1.

6.2. Sub Bab (jika ada) ditulis dengan format huruf capitalize each word, rata kiri, bold, font Arial 10, spasi 1.

\section{Cara Penyajian Tabel}

7.1. Judul tabel ditampilkan di bagian atas tabel, rata kiri halaman, menggunakan font Arial 9.

7.2. Tulisan "Tabel", "Nomor", dan judul tabel ditulis dengan format huruf sentence case.

7.3. Gunakan angka Arab (1,2,3,dst) untuk penomoran judul tabel.

7.4. Tabel ditampilkan rata kiri halaman.

7.5. Jenis dan ukuran font untuk isi tabel menggunakan Arial ukuran 8-9 dengan spasi 1.

7.6 Tabel yang dicantumkan tanpa menggunakan vertical line, hanya menggunakan horizontal line pada bagian judul dan bagian bawah tabel.

7.7. Pencantuman sumber atau keterangan diletakkan di bawah tabel, rata kiri, italic, menggunakan font Arial 8.

\section{Cara Penulisan Gambar}

8.1. Gambar dapat dalam bentuk grafik, matriks, foto, diagram, dan sejenisnya ditampilkan di tengah halaman (centered).

8.2. Judul gambar ditulis di bawah gambar, menggunakan font Arial 9, ditempatkan di tengah halaman (centered). 
8.3. Tulisan "Gambar", "Nomor", dan judul tabel ditulis dengan format huruf sentence case.

8.4. Gunakan angka Arab (1,2,3, dst) untuk penomoran judul gambar.

8.5. Pencantuman sumber atau keterangan diletakkan di bawah judul gambar, rata kiri, italic, menggunakan font Arial 8.

\section{Cara dan Contoh Penulisan Kutipan (Sitasi)}

9.1. Penulisan kutipan (Sitasi) menggunakan metode Chicago Style

9.1.1. Nama belakang atau nama keluarga pengarang pertama, kedua dan ketiga. Untuk karya yang ditulis oleh lebih dari 3 (tiga) orang pengarang, gunakan "et al." atau "dkk" setelah nama belakang pengarang pertama (hanya pengarang pertama yang disebutkan).

9.1.2. Tahun terbit. Antara nama pengarang atau badan korporasi dengan tahun terbit hanya dibatasi dengan satu spasi (tanpa tanda baca lainnya).

9.1.3. Jika dalam satu paragraph/kalimat menggunakan lebih dari 1 (satu) kutipan/sitasi Contoh : maka digunakan tanda penghubung berupa (;)

a. Menurut Catur (2012), penambahan pelarut berpengaruh kepada ....

b. .......... akan berpengaruh kepada kecepatan reaksi (Catur 2012).

c. ..........akan berpengaruh kepada kecepatan reaksi (Catur 2012; Winarno 2009; Raffi et al. 2007)

\section{Cara dan Contoh Penulisan Daftar Pustaka}

10.1. Urutan dalam daftar pustaka ditulis sesuai dengan urutan huruf abjad nama penulis yang dikutip dalam naskah (berdasarkan alfabetis).

10.2. Daftar pustaka ditulis sesuai dengan metode Chicago Manual of Style 16th edition (authordate).

10.3. Berikut adalah contoh cara penulisan daftar pustaka dari berbagai sumber yang berbeda.

\subsubsection{Jurnal dengan volume dan nomor}

Pengarang. Tahun. Judul naskah. Nama jurnal. Volume (nomor) : Halaman

Setiap huruf awal nama jurnal ditulis dengan huruf kapital.

Contoh : Obaidat, I.M., B. Issa, and Y. Haik. 2011. "The role of aggregation of ferrite nanoparticles on their magnetic properties". Journal of nanoscience and nanotechnology 11 (5) : 3882-3888.

\subsubsection{Buku (satu orang pengarang)}

Pengarang. Tahun. Judul buku. Edisi. Kota : Penerbit

Contoh : Suprapto, H. 2004. "Petani bangkit: napak tilas perjuangan kaum tani Indonesia". Jakarta : Kuntum Satuhu.

10.2.3. Buku (dua atau tiga orang pengarang)

Pengarang. Tahun. Judul buku. Edisi. Kota : Penerbit

Contoh : Domsch, K.H., W. Garns, and T.H. Anderson. 1980. "Compendium of soil fungi". Vol. 1. London : Academic Press.

\subsubsection{Buku (lebih dari tiga orang pengarang)}

Pengarang. Tahun. Judul buku. Edisi. Kota : Penerbit

Contoh : Lim, M.S., Y.D. Yun, C.W. Lee, S.C. Kim, S.K. Lee, and G.S. Chung. 1991. "Research status and prospects of direct seeded rice in Korea". Los Banos: IRRI.

\subsubsection{Skripsi, Tesis, dan Disertasi}

Pengarang. Tahun. Judul skripsi/tesis/disertasi. Skripsi/tesis/disertasi. Nama perguruan tinggi, Kota. Negara.

Contoh : Raffi, M. 2007. "Synthesis and characterization of metal nanoparticles". PhD Dissertation. Pakistan Institute of Eng. And Applied Sciences, Islamabad. Pakistan

\subsubsection{Artikel dalam Prosiding}

Pengarang. Tahun. Judul artikel. Dalam : Penulis. Judul buku/prosiding. Kota : Penerbit : Halaman 
Contoh : Afifah, N. dan E. Sholichah. 2009. "Pemanfaatan virgin coconut oil (VCO) dalam sediaan hand body lotion dan uji stabilitasnya". Dalam : Prosiding seminar nasional Teknik Kimia Universitas Parahyangan : 178 - 184.

10.2.7. Website

Pengarang. Tahun. Judul artikel. URL yang terdiri dari protocol/site/path/file. Tanggal akses

Contoh : Wolman, David. 2008. Fossil feces is earliest evidence of an America humans. $\quad$ http://news.nationalgeographic.com/news/2008/04/080403first-americans.html. (Accessed April 4, 2008)

Pranamuda, H. 2001. Pengembangan plastik biodegradable berbahan baku pati tropis. http://bersihplanet.multiply.com/journal. (diakses pada 21 Desember 2010) 


\section{Simbol Matematis}

Simbol atau persamaan matematis harus dikemukakan secara jelas.

Tabel

Tabel diberi nomor urut sesuai dengan keterangan di dalam teks. Setiap tabel diberi judul yang singkat dan jelas diletakkan di atas tabel, sehingga setiap tabel dapat dipandang berdiri sendiri sedangkan untuk gambar atau grafik judulnya diletakkan di bawah gambar/ grafik. Singkatan kata perlu diberi catatan kaki atau keterangan. Keterangan tabel diletakkan di bawah tabel.

\section{Pengolahan Naskah}

Redaksi melakukan penilaian, koreksi dan perbaikan. Kriteria penilaian meliputi : kebenaran isi, tingkat keaslian, kejelasan uraian dan kesesuaian dengan misi publikasi. Redaksi akan mengembalikan naskah kepada penulis untuk diperbaiki sesuai dengan saran redaksi dan naskah yang tidak dapat diterbitkan akan diberitahukan.

\section{Ulasan dan tinjauan ilmiah}

Ulasan sebaiknya merupakan tinjauan mengenai masalah yang terkini (up to date) dari industri kimia (organik dan anorganik) serta teknologi dan bahan kemasan.

\section{KESIMPULAN}

Ditulis dengan ringkas hasil-hasil yang didapat.

\section{DAFTAR PUSTAKA}

Daftar Pustaka disusun menurut abjad dan ditulis sesuai penulisan daftar pustaka dengan metode Chicago Manual of Style 16th edition (authordate). 
Iwan Syahjoko Saputra1, Siti Suhartati1, Yoki Yulizar2, Sudirman3

${ }^{1}$ Akademi Kimia Analis Caraka Nusantara

Jl. Tugu Raya Komplek Timah, Cimanggis, Depok

${ }^{2}$ Universitas Indonesia

Kampus Baru UI, Depok

${ }^{3}$ Badan Tenaga Nuklir Nasional

Kawasan Puspitek, Serpong, Tanggerang Selatan

\section{E-mail: iwan28chemistry@gmail.com}

Green Synthesis Nanopartikel ZnO Menggunakan Media Ekstrak Daun Tin (Ficus carica Linn)

\section{J. Kimia Kemasan April 2020, Vol. 42 No. $1: 1$ - 6}

Tujuan penelitian ini adalah sintesis nanopartikel $\mathrm{ZnO}$ menggunakan metode green synthesis dengan memanfaatkan ekstrak daun tin (Ficus carica Linn) sebagai media. Gugus aktif yang terkandung dalam ekstrak daun tin berperan sebagai media sekaligus sumber basa alami dalam sintesis nanopartikel $\mathrm{ZnO}$ dan berpengaruh terhadap sifat optik, bentuk morfologi serta karakteristik nanopartikel ZnO. Hasil karakterisasi nanopartikel ZnO menggunakan Spektrofotometer UV-Vis menunjukkan puncak serapan pada panjang gelombang $260 \mathrm{~nm}$ dengan nilai absorbansi 0,6 . Hasil UV-Vis DRS menunjukkan nilai bandgap nanopartikel $\mathrm{ZnO}$ sebesar $3,32 \mathrm{eV}$ dan hasil karakterisasi XRD menunjukkan tiga puncak spesifik kristalinitas nanopartikel $\mathrm{ZnO}$ yaitu pada 2 teta: $30.71^{\circ}$ $33.36^{\circ}$, dan $37.20^{\circ}$ dengan ukuran kristal $15,9 \mathrm{~nm}$. FTIR menunjukkan adanya vibrasi $\mathrm{ZnO}$ pada bilangan gelombang $492 \mathrm{~cm}^{-1}$ dan puncak serapan gugus fungsi $\mathrm{OH}$ pada bilangan gelombang $3501 \mathrm{~cm}^{-1},-\mathrm{C}=\mathrm{O}$ pada bilangan gelombang $2490 \mathrm{~cm}^{-1}$, C-O-H pada $1397 \mathrm{~cm}^{-1}$, dan gugus fungsi amina pada $913 \mathrm{~cm}^{-1}$. Hal ini mengindikasikan bahwa dalam ekstrak daun tin terdapat metabolit sekunder yang dapat berperan sebagai media dalam pembentukan nanopartikel ZnO. Hasil SEM-EDS menunjukkan bentuk morfologi nanopartikel $\mathrm{ZnO}$ berbentuk seperti kapas dengan perbandingan massa unsur $\mathrm{Zn}$ dan O adalah $30,24 \%$ dan $69,76 \%$. Hasil PSA dan PZC menunjukkan nanopartikel $\mathrm{ZnO}$ memiliki nilai PDI sebesar 0,739 dan distribusi rata-rata ukuran partikel sebesar 49,62 dengan nilai zeta potensial $-23 \mathrm{mV}$.

Kata Kunci: Green synthesis, Nanopartikel ZnO, Ficus carica Linn

Aswin Falahudin ${ }^{1}$, Salprima Yudha $\mathrm{S}^{1^{*}}$, Irfan Gustian ${ }^{1}$, Morina Adfa ${ }^{1}$, Charles Banon ${ }^{1}$, Teja Dwi Sutanto ${ }^{1}$

1Jurusan Kimia, Fakultas Matematika dan IImu Pengetauan Alam, Universitas Bengkulu

Jalan W.R, Supratman, Kandang Limun, Kota Bengkulu, Indonesia

\section{E-mail:salprima@unib.ac.id,sp.yudha.s@gmail.com}

Ekstrak Bunga Tapak Kuda (Ipomoea pescaprae L. Sweet) Sebagai Medium Sintesis Nanopartikel Emas

J. Kimia Kemasan April 2020, Vol. 42 No. $1: 7$ - 13
Pada penelitian ini, nanopartikel emas disiapkan melalui pendekatan green synthesis menggunakan ekstrak air bunga tapak kuda (Ipomoea pescaprae L. Sweet). Nanopartikel emas yang dihasilkan dianalisis menggunakan spektrofotometer UV-Vis, Mikroskop Leica, Particle Size Analyzer (PSA), Spektrofotometer Fourier Transform Infra-Red (FTIR) dan X-ray Difractometer (XRD). Hasil pengukuran PSA menunjukkan ukuran partikel terbaik, diperoleh dengan menggunakan perbandingan volume $1 \mathrm{~mL}$ larutan $\mathrm{HAuCl}_{4}$ dengan $9 \mathrm{~mL}$ ekstrak yang menghasilkan partikel dengan ukuran rata-rata $16,3 \mathrm{~nm}$. Hasil penampakan dengan mikroskop cahaya, memperlihatkan partikel berbentuk bulat. Pergeseran bilangan gelombang pada spektrum infra-merah menunjukkan adanya interaksi antara metabolit sekunder dari ekstrak dengan material emas. Analisis XRD menunjukkan bahwa nanopartikel emas telah dapat dihasilkan dari kondisi reaksi ini.

Kata kunci : Nanopartikel emas, Ipomoea pescaprae (L) Sweet, Sintesis

Kendri Wahyuningsih ${ }^{1}$ dan Lovy Perdani ${ }^{2}$

${ }^{1}$ Balai Besar Litbang Pascapanen Kementrian Pertanian Jl. Tentara Pelajar No.12, Cimanggu, Bogor, Jawa Barat ${ }^{2}$ Fakultas Biologi, Universitas Gadjah Mada

Jl. Teknika Selatan, Sinduadi, Sleman, Yogyakarta

\section{E-mail:kendriwahyuni@gmail.com}

Aktivitas Antimikroba Partikel Nano $\mathrm{CaO}$ dari Kulit Kerang Mutiara (Pinctada maxima)

J. Kimia Kemasan April 2020, Vol. 42 No. 1 : 14 - 19

Kulit kerang mutiara (Pinctada maxima) mengandung senyawa oksida logam $\mathrm{CaO}$ yang berpotensi sebagai antimikroba. Penelitian ini bertujuan untuk mengetahui aktivitas partikel nano $\mathrm{CaO}$ dari kulit kerang mutiara laut $(P$. maxima) sebagai antimikroba. $\mathrm{CaO}$ diperoleh dari hasil kalsinasi kulit kerang mutiara laut ( $P$. maxima) pada suhu $650^{\circ} \mathrm{C}$ selama 24 jam. Pembuatan partikel nano $\mathrm{CaO}$ menggunakan shaker mill dengan kondisi proses penggilingan selama 3 jam, kecepatan kocok shaker mill $750 \mathrm{rpm}$, rasio berat antara serbuk kulit $P$. maxima dengan bola-bola penggiling 1:10, diameter bola-bola penggiling 5 $\mathrm{mm}$ dan kapasitas volume pengisian jar shaker mill $55 \%$. Karakterisasi partikel nano $\mathrm{CaO}$ menggunakan metode analisis X-Ray Fluorescence (XRF), X-Ray Diffraction (XRD), Brunauer Emmett Teller (BET), dan Transmission Electron Microscope (TEM). Metode pengujian aktivitas antimikroba dilakukan menggunakan metode difusi cakram. Hasil pengamatan menunjukkan bahwa kulit kerang $P$. maxima mengandung senyawa $\mathrm{CaO}$ sebesar $93,9 \%$, ratarata ukuran kristalin partikel $\mathrm{CaO} 92,66 \mathrm{~nm}$, dan luas permukaan spesifik 16,4 m2/g. Partikel nano $\mathrm{CaO}$ mampu menghambat pertumbuhan bakteri gram negatif ( $S$. dysenteriae), bakteri gram positif ( $S$. epidermidis), dan jamur (C. albicans) dengan rata-rata daya hambat secara berurutan sebesar $11,96 \mathrm{~mm}, 12,77 \mathrm{~mm}$, dan $12,82 \mathrm{~mm}$.

Kata kunci: Pinctada maxima, Partikel nano, Kalsium oksida, Bakteri gram positif, Bakteri gram negatif 
Meri Suhartini ${ }^{1}$, Santoso P. ${ }^{1}$, E. Ernawati ${ }^{2}$, dan A.Y. Panjaitan $^{2}$

${ }^{1}$ Pusat Aplikasi Isotop Radiasi, PAIR-BATAN

Jl. Lebak Bulus Raya no.49 Jakarta

${ }^{2}$ Fakultas Matematika dan IImu Pengetahuan Alam

Universitas Padjadjaran, Jatinangor-Bandung

E-mail : meri@batan.go.id

Peningkatan Sifat Fisika Kimia Membran Selulosa Asetat Menggunakan Polifungsional Monomer Trimethallyl Isocyanurate

J. Kimia Kemasan April 2020, Vol. 42 No. $1: 20$ - 28

Membran selulosa asetat dapat digunakan untuk pemurnian minyak atsiri menggunakan teknik pemisahan non pori, akan tetapi membran ini mempunyai sifat fisika dan kimia yang rendah, sehingga mudah koyak dan rusak saat digunakan. Penelitian ini bertujuan untuk meningkatkan sifat fisika dan kimia membran selulosa asetat menggunakan polifungsional monomer Trimethallyl isocyanurate (TMAIC). Membran tersebut diharapkan mempunyai kekuatan tarik tinggi dan derajat penggembungan rendah, sehingga memenuhi kriteria untuk digunakan pada pemurnian minyak atsiri. Selulosa asetat-TMAIC disintesis dengan cara mengisolasi selulosa dari sekam padi, kemudian dibuat selulosa asetat menggunakan asam asetat glasial. Polifungsional monomer TMAIC ditambahkan sebagai agen pengikat silang. Sinar gamma digunakan sebagai inisiator reaksi pembentukan ikatan silang antara selulosa-TMAICselulosa. Hasil penelitian menunjukkan bahwa penambahan TMAIC pada selulosa asetat yang digabungkan dengan iradiasi sinar gamma, menyebabkan penurunan derajat penggembungan dan peningkatan kekuatan tarik secara signifikan, yaitu masing-masing sebesar $65,48 \%$ dan $53,24 \%$. Karakterisasi menggunakan Fourier Transform Infrared (FTIR) membuktikan adanya pembentukan ikatan silang selulosa asetat dengan TMAIC.

Kata kunci: Membran selulosa asetat, TMAIC, Ikatan silang, Sinar gamma
Eviomitta Rizki Amanda', Khoirun Nisyak', Yulianto Ade Prasetya $^{1}$

${ }^{1}$ Program Studi DIII Teknologi Laboratorium Medis, STIKES Rumah Sakit Anwar Medika

Jl. Raya By Pass KM 33 Krian, Sidoarjo, Jawa Timur (61253)

\section{E-mail: eviomittarizki@gmail.com}

Pengembangan Bioplastik Antibakteri Morganella morganii sebagai Kemasan Makanan

J. Kimia Kemasan April 2020, Vol. 42 No. $1: 29-36$

Bioplastik antibakteri berbahan komposit biopolimer agarosa-kitosan telah berhasil dikembangkan dengan menggunakan gliserol sebagai plastisiser dan emulsi minyak serai dapur sebagai agen antibakteri. Komposit plastik agarosa-kitosan-emulsi minyak serai dapur dibuat dengan menggunakan metode casting. Beberapa konsentrasi emulsi minyak serai dapur seperti $1 \% \mathrm{v} / \mathrm{v}$, $2 \% \mathrm{v} / \mathrm{v}, 3 \% \mathrm{v} / \mathrm{v}, 4 \% \mathrm{v} / \mathrm{v}$, dan $5 \% \mathrm{v} / \mathrm{v}$ ditambahkan ke dalam larutan biopolimer dan dioptimasi dengan mengamati daya hambatnya terhadap bakteri Morganella morganii dengan konsentrasi $10^{6} \mathrm{cell} / \mathrm{mL}$. Hasil optimasi menunjukkan bahwa konsentrasi optimum emulsi minyak serai dapur dalam larutan biopolimer untuk menghambat bakteri Morganella amorganii adalah $1 \% \mathrm{v} / \mathrm{v}$ dengan luas area daya hambat sebesar $16 \mathrm{~cm}^{2}$. Komposisi bioplastik yang optimum kemudian dikarakterisasi untuk mengetahui sifat fisik dan mekaniknya. Hasil pengukuran menunjukkan bahwa ketebalan komposit bioplastik dengan konsentrasi emulsi minyak serai $1 \%$ sebesar $0,0225 \mathrm{~mm}$ mengalami peningkatan sebesar $70 \%$ sampai $80 \%$ dari biopolimer agarosa dan kitosan secara terpisah. Uji sifat fisik dan mekanik dari bioplastik ditunjukkan oleh besarnya tensile strength (TS) dan elongation break (EB) yakni sebesar $51,28 \mathrm{MPa}$ dan $4 \%$, serta nilai water vapor permeability (WVP) bioplastik menggunakan emulsi minyak serai $1 \%$ sebesar $0,0097 \mathrm{~g} / \mathrm{cm}^{2}$ hari yakni lebih kecil dari WVP agarosa dan kitosan secara terpisah. Morfologi permukaan plastik dianalisis menggunakan Scanning Electron Microscopy (SEM) dan menunjukkan permukaan yang halus dan homogen.

Kata kunci: Kemasan Antibakteri, Agarosa, Kitosan, Emulsi Minyak Serai Dapur, Morganella morganii 


\section{UCAPAN TERIMA KASIH}

Dewan Redaksi mengucapkan terima kasih kepada mitra bestari sebagai reviewer yang telah menelaah dan memberi masukan serta rekomendasi dalam rangka menjaga mutu jurnal ini sesuai kaidah-kaidah karya tulis ilmiah. Adapun namanama mitra bestari sebagai berikut :

\begin{tabular}{|c|l|c|}
\hline NO & \multicolumn{1}{|c|}{ NAMA } & INSTANSI \\
\hline 1 & Prof. Dr. Ir. Slamet, M.T. & UI \\
\hline 2 & Dr. Sudirman, MSc, APU & BATAN \\
\hline 3 & Dr. Etik Mardliyati & BPPT \\
\hline 4 & Dr. Mochamad Chalid & UI \\
\hline 5 & Nofrijon Sofyan, Ph.D & UI \\
\hline 6 & Prof. Dr. Andria Agusta & LIPI \\
\hline 7 & Dr. Endang Warsiki & IPB \\
\hline 8 & Dedi Noviendri, Ph.D & KKP \\
\hline 9 & Prof. Dr. Irmanida Batubara & IPB \\
\hline 10 & Fadlilatul Taufany, ST., Ph.D. & ITS \\
\hline
\end{tabular}

